\title{
ACMEOLOGICAL ASPECT OF PROFESSIONAL ACTIVITY OF INDUSTRIAL TRAINING MASTERS
}

\section{АКМЕОЛОГІЧНИЙ АСПЕКТ ПРОФЕСІЙНОЇ ДІЯЛЬНОСТІ МАЙСТРІВ ВИРОБНИЧОГО НАВЧАННЯ}

\author{
Taisiia CHEREMISINA, \\ Candidate of Pedagogical Sciences, \\ Senior Lecturer \\ Таїсія ЧЕРЕMICIHA, \\ кандидат педагогічних наук, \\ старший викладач \\ cheremisina.taisiya@ukr.net \\ https://orcid.org/0000-0002-2593-506X \\ Berdiansk State Pedagogical \\ Бердянський державний \\ University \\ 4, Schmidta St., Berdiansk, \\ Zaporizhzhia region, 71100 \\ педагогічний університет \\ Original manuscript received: October 07, 2021 \\ Revised manuscript accepted: December 15, 2021
}

\begin{abstract}
The article reveals the essence of the acmeological approach in the field of education, which is chosen to create conditions that encourage the individual to progressive self-development, self-organization and, accordingly, professional self-improvement in achieving the optimal level of professional development. The internal conditions for achieving professional acme of masters of industrial training are determined: positive motivation to achieve the expected results with a high level of demands and self-realization; focus on the ascending trajectory of the professional path; productive activity in performing professional functions; the desire to preserve and increase their achievements; the ability to mobilize potential opportunities (motivational, intellectual, operational, emotional and volitional) and recover from physical and psychological stress. The external conditions for the emergence of acme masters of industrial training are determined: assistance in mastering the means necessary for the development of pedagogical thinking, creativity, individuality of the personality and his spiritual potential; ensuring the implementation of personally and socially significant prospects in professional activities; stimulating the process of self-improvement; strengthening the integration role of acme-psychological support as a holistic and continuous process of study, analysis, formation, development, self-development and correction of the specialist's personality; development and realization of the corresponding maintenance, models, algorithms of acmeological technologies, adequate means of methodical maintenance, diagnostics and assessment of the professional developmentdynamics.

The tools of accumulation of professional activityresults in the context of acme are characterized. In particular, the acmeogram, which indicates the types of professional activities and personality qualities that lead not only to the masters of industrial training socially necessary results, but also provide progressive development and professional development, promotion to high levels of professionalism; portfolio as a description in any form of educational and professional achievements of industrial trainingmasters, which includes information on the main stages of activity, professional development, including the achieved results, information on participation in projects, publications, methodological developments, etc.
\end{abstract}

Key words: acmeology, master of industrial training, vocational education institution. 
Вступ. Концепція розвитку педагогічної освіти (2018) наголошує на необхідності подолання протиріччя між суспільним запитом на висококваліфрікованих педагогічних працівників та існуючим рівнем готовності сучасних фахівців до сприйняття та реалізації освітніх реформ України. Важливим чинником такого дисбалансу виступає зорієнтованість моделей професійного розвитку педагогічних працівників на формальне дотримання встановлених вимог, а не на особистісне та професійне зростання педагогічних працівників. Як зазначено в стандарті вищої освіти за спеціальністю 015 «Професійна освіта (за спеціалізаціями)» для першого рівня вищої освіти (2019), від бакалаврів з професійної освіти, що мають право на працевлаштування в закладах професійної (професійнотехнічної) освіти, очікується ефективність у здійсненні освітньої діяльності із професійної підготовки технічних фрахівців, кваліфікованих робітників і працівників сфери торгівлі та послуг підприємств, установ та організацій галузі або сфрери відповідно до спеціалізації. Успішність такої діяльності залежить від безперервного професійного розвитку педагогічних працівників, зокрема майстрів виробничого навчання, забезпечуючи розширення професійних можливостей, пізнавальних інтересів та формування творчої індивідуальності.

Подолання потреби професійного розвитку полягає в оновленні цілей й змісту професійної діяльності майстрів виробничого навчання на основі особистісних орієнтацій. Акмеологічне наповнення складників професійної діяльності та відповідний методичний супровід сприятиме саморозвитку, самоорганізації та професійному самовдосконаленню майстрів виробничого навчання в досягненні оптимального рівня профресійного розвитку. Останнім часом підґрунтям наукових досліджень підготовки та професійного розвитку педагогічних працівників стали ідеї загальної та педагогічної акмеології (В. Вакуленко, 2008; О. Дубасенюк, 2011; О. Кривильова, 2017, 2021; І. Ніколаєску, 2012; С. Пальчевський, 2008; Л. Рибалко, 2007 та інші), що доводять наявність значного потенціалу акмеологічного проєктування або самопроєктування профресійного шляху особистості. Об'єднувальним фрактором цих процесів $€$ акмеологічний підхід, який забезпечує вивчення і здійснення практичного вдосконалення педагогічних працівників через перетворення наявного професійного рівня розвитку у вищий, оптимальний, що є актуальним для сьогодення. Мета дослідження - теоретично обґрунтувати внутрішні та зовнішні умови професійного зростання майстрів виробничого навчання на основі акмеологічного підходу. Для досягнення мети сформульовані такі завдання: 1) розкрити сутність акмеологічного підходу в освітній галузі; 2) визначити внутрішні умови досягнення професійного акме майстрів виробничого навчання; 3) визначити зовнішні умови появи акме майстрів виробничого навчання; 4) схарактеризувати інструментарій накопичення результатів профресійної діяльності в контексті акме.

Методи та методики дослідження. Методика проведення дослідження містить аналіз законодавчих та нормативно-правових документів для визначення вимог до професійного розвитку майстрів 
виробничого навчання; аналіз психолого-педагогічної літератури для розкриття сутності акмеологічного підходу та умов його реалізації в професійній діяльності майстрів виробничого навчання.

Результати та дискусії. В освіті акмеологічний підхід виступає новим науково-методологічним напрямом, який стосується розробки моделей та проєктів становлення людини до рівня її найвищих досягнень, удосконалення її як індивіда, особистості, суб'єкта діяльності, індивідуальності. Зважаючи на те, що професійний розвиток майстрів виробничого навчання $є$ процесом, у якому змінюються життєві та професійні плани, відбувається перебудова структури особистості та визначається провідна діяльність, акмеологічний підхід обрано для створення умов, що спонукають фахівців до прогресивного саморозвитку, самоорганізації та відповідно професійного самовдосконалення в досягненні оптимального рівня професійного зростання.

Забезпечення професійного розвитку майстрів виробничого навчання має здійснюватися 3 урахуванням сутнісних характеристик акмеологічного підходу, що передбачає: створення умов, які стимулюють прагнення до самореалізації, творчості, успіху й рефлексії (тобто професійних та особистісних досягнень); вивчення теоретичних основ та практичне освоєння фахівцями акмеологічних технологій самопізнання, саморегуляції і самореалізації; реалізація особистісно-професійного потенціалу в процесі цілеспрямованого переорієнтування поглядів, переконань, думок, ідейних принципів фахівців на розвиток природи самості; розуміння особистісно-професійного розвитку як здатності до проєктування фахівцями мети власної діяльності, спрямованої на високий результат, життєві успіхи, моделювання маршруту щодо професійного самовдосконалення з урахуванням власних потенційних здібностей і потреб суспільства; орієнтування на суб'єктивну (особистісну) значущість професійного «акме», яка виявляє досягнення, що перевищують попередні результати в праці фахівця; урахування позиції, що професійні «акме» можуть виявлятися в оволодінні високими рівнями професійної діяльності. Так, внутрішніми умовами досягнення професійного акме майстрів виробничого навчання у професійній діяльності визначено: позитивна мотивація на досягнення очікуваних результатів з високим рівнем домагань та самореалізації; спрямованість на висхідну траєкторію професійного шляху; продуктивна активність у виконанні професійних функцій; прагнення до збереження та примноження своїх досягнень; здатність мобілізувати потенційні можливості (мотиваційні, інтелектуальні, операційно-діяльнісні, емоційно-вольові) та відновлюватися після фізичного та психологічного навантаження.

Спрямованість до вершин особистісного, професійного розвитку й самовдосконалення характеризує акмеологічну компетентність або акмеологічні властивості майстрів виробничого навчання. Під акмеологічною компетентністю розуміємо інтегральну готовність і здатність зрілої особистості будувати свій поступовий психічний та професійний розвиток із постійним ускладненням завдань і зростанням рівня досягнень, котрі 
найбільш повно реалізують психологічні ресурси людини. Остання включає в себе якості особистості (акмеологічні знання, тобто обізнаність, поінформованість про те, які досягнення можливі у сфрері професійного розвитку, їхні рівні, варіанти; акмеологічні вміння - прийоми, способи, технології досягнень у сфрері професійного розвитку, прийоми розрізнення, оцінювання різних видів акме; акмеологічні якості, які забезпечують рух до намічених досягнень, до яких ми відносимо передусім акме-мотивацію (спрямованість на розв'язання акмеологічних завдань профресійного розвитку, забезпечення його поступового характеру) та акме-здібності (індивідуальнопсихологічні властивості, які забезпечують підтримку поступального висхідного вектора професійного розвитку, включають здатність будувати варіанти акмеограм свого розвитку, обирати та реалізувати прийоми та технології переходу з одного рівня професіоналізму на інший, більш високий, здатність долати перепони на шляху досягнення акме).

Зміст та рівні акмеологічної компетентності відображаються в акмеограмі, документі, у якому зазначено вимоги до діяльності й особистості успішного фахівця. Тобто, наведено види професійної діяльності та якості особистості, що сприяють не просто отриманню майстрами виробничого навчання соціально необхідного результату, але й забезпечують поступальний розвиток i професійне вдосконалення, просування до високих рівнів професіоналізму. Акмеограма може містити: цілі (очікувані результати); вибір моделі розвитку; можливі індивідуальні показники професіоналізму, плановані як результати розвитку; експертно-діагностичні методи збору, аналізу та інтерпретації інформації, отриманої про фахівця; модель реальних професійних якостей; модель реальних професійних здібностей; модель реальних умінь і навичок; техніки впливу і самовпливу в процесі професійної діяльності; техніки корекції і самокорекції наявного стану; техніки конструювання й розвитку професійного «акме».

Зовнішніми умовами появи акме у професійному розвитку $\epsilon$ сприятливе й акмеологічно насичене профресійне середовище, що спонукає майстрів виробничого навчання до розкриття потенційних можливостей, як-то: допомога в оволодінні засобами, необхідними для розвитку педагогічного мислення, творчості, індивідуальності особистості; забезпечення реалізації особистісно і соціально значущих перспектив у професійній діяльності; стимулювання процесу самовдосконалення; посилення інтеграційної ролі акме-психологічного супроводу як цілісного й безперервного процесу вивчення, аналізу, формування, розвитку, саморозвитку й корекції особистості фрахівця; розробка й реалізація відповідного змісту, моделей, алгоритмів акмеологічних технологій, адекватних засобів методичного забезпечення, діагностики й оцінки динаміки професійного розвитку. Так, акмеологічні технології включають систему завдань, способи досягнення майстрами виробничого навчання високих рівнів професіоналізму, а також підпорядковану їм сукупність методів, технік і прийомів. Основне завдання акмеологічних технологій сформувати й закріпити в самосвідомості майстрів виробничого навчання 
затребувану необхідність у самопізнанні, саморозвитку й самореалізації. Виконуючи за допомогою акмеологічних технологій усвідомлену активну роль, фахівці набувають технологічних здібностей до самооцінки, самопрограмування, самоорганізації, саморегуляції, самоствердження, що формує здатність самостійно впливати на професійні цілі, систему очікувань і прогнозів щодо майбутнього, оцінювати їх досягнення і тим самим впливати на власну стратегію розвитку та самореалізації.

Вибір акмеологічних технологій здійснюється на основі акмеограми майстрів виробничого навчання. Завданнями методистів та психологів закладів професійної (професійно-технічної) освіти з надання допомоги майстрам виробничого навчання у професійному зростанні $є$ : здійснення діагностики рівня професійного розвитку; стимулювання прагнення до подальшого професійного росту; виявлення умов, що перешкоджають професійному розвитку; консультування про можливі акмеологічні технології, що сприяють професійному вдосконаленню. Набуття практичного досвіду майстрів виробничого навчання здійснюється в процесі розроблення методичних напрацювань (уроків, сценаріїв), у тому числі, цифрових освітніх ресурсів (відео- та аудіоматеріалів, електронних підручників, сайтів, блогів, тестових середовищ тощо). Безперервний професійний розвиток майстрів виробничого навчання може здійснюватися шляхом фрормальної, неформальної та інформальної освіти, а результати накопичуватися в електронному портфоліо, що розміщується на веб-сайті закладу освіти або його засновника. Портфоліо включає відомості про основні етапи діяльності з професійного вдосконалення, інформації про участь у проєктах, публікації, методичні розробки тощо.

Висновки. Забезпечення профресійного розвитку майстрів виробничого навчання має здійснюватися 3 урахуванням сутнісних характеристик акмеологічного підходу. Створення акмеологічно насиченого професійного середовища сприятиме реалізації потенційних можливостей майстрів виробничого навчання та досягненню ними професійних акме.

\section{Література}

Вакуленко В. М. Акмеологічний підхід у теорії та практиці вищої педагогічної освіти України, Білорусі, Росії : автореф. дис. ... докт. пед. наук : 13.00.01. Луганськ, 2008. 58 с.

Кривильова О. А. Психолого-педагогічна підготовка майбутніх викладачів професійно-технічних навчальних закладів: теоретичний та методичний аспекти : монографія. Бердянськ : БДПУ, 2017. 305 с.

Ніколаєску І. О. Практичні основи акмеологічного розвитку особистості в умовах освітньо-інформаційного простору: навчально-методичний посібник. Черкаси : ОІПОПП, 2012. 54 с.

Пальчевський С. С. Акмеологія : навч. посіб. Київ : Кондор, 2008. 398 с.

Професійна педагогічна освіта: акме-синергетичний підхід : монографрія / за ред. О. А. Дубасенюк. Житомир : Вид-во ЖДУ ім. І. Франка, 2011. 389 с.

Про затвердження концепції розвитку педагогічної освіти : наказ Міністерства освіти і науки України від 16.07.2018 p. №776. URL : https://mon.gov.ua/ua/npa/prozatverdzhennya-koncepciyi-rozvitku-pedagogichnoyi-osviti 
Про затвердження стандарту вищої освіти 015 «Професійна освіта (за спеціалізаціями)» для першого (бакалаврського) рівня вищої освіти : Наказ МОН України від 21.11.2019 р № 1460. URL : https://mon.gov.ua/storage/app/media/vishchaosvita/zatverdzeni\%20standarty/2019/11/22/2019-11-22-015-B.pdf

Рибалко Л. С. Методолого-теоретичні засади професійно-педагогічної самореалізації майбутнього вчителя (акмеологічний аспект) : монографія. Запоріжжя : ЗДМУ, 2007. 443 с.

Kryvylova O., Sosnickaya N., Oleksenko K., Oleksenko R., \& Khavina I. (2021). The aqmeological framework for modern higher education as a step towards sustainable development of society. Linguistics and Culture Review, 5(S3), 55-64. URL : https://doi.org/10.37028/lingcure.v5nS3.1369

\section{References}

Vakulenko, V. (2008). Akmeolohichnyi pidkhid u teorii ta praktytsi vyshchoi pedahohichnoi osvity Ukrainy, Bilorusi, Rosii [Akmeological approach in the theory and practice of higher pedagogical education in Ukraine, Belarus, Russia]. (Extended abstract of Doctor`s thesis). Lugansk National Taras Shevchenko University. Lugansk [in Ukrainian].

Kryvylova, O. (2017). Psykholoho-pedahohichna pidhotovka maibutnikh vykladachiv profesiino-tekhnichnykh navchalnykh zakladiv: teoretychnyi ta metodychnyi aspekty [Psychological and pedagogical training of future teachers of vocational schools: theoretical and methodological aspects]. Berdiansk : BDPU [in Ukrainian].

Nikolaiesku, I. (2012). Praktychni osnovy akmeolohichnoho rozvytku osobystosti $v$ umovakh osvitno-informatsiinoho prostoru [Practical bases of acmeological development of personality in the conditions of educational and information space]. Cherkasy : OIPOPP [in Ukrainian].

Palchevskyi, S. (2008). Akmeolohiia [Acmeology]. Kyiv: Kondor [in Ukrainian].

Dubaseniuk, O. A. (Ed.) (2011). Profesiina pedahohichna osvita: akmesynerhetychnyi pidkhid: monohrafiia [Professional pedagogical education: acmesynergetic approach]. Zhytomyr : Vyd-vo ZhDU im. I. Franka [in Ukrainian].

On approval of the concept of development of pedagogical education. №776. (2018). Oficijny j sajt Ministerstva osvity i nauky Ukrayiny [Official site of the Ministry of Education and Science of Ukraine]. URL: https://mon.gov.ua/ua/npa/prozatverdzhennya-koncepciyi-rozvitku-pedagogichnoyi-osviti [in Ukrainian].

On approval of the standard of higher education 015 «Professional education (by specializations)» for the first (bachelor's) level of higher education. №1460. (2019). Oficijny j sajt Ministerstva osvity i nauky Ukrayiny [Official site of the Ministry of Education and Science of Ukraine]. URL: https://mon.gov.ua/storage/app/media/vishchaosvita/zatverdzeni\%20standarty/2019/11/22/2019-11-22-015-B.pdf [in Ukrainian].

Rybalko, L. (2007). Metodoloho-teoretychni zasady profesiino-pedahohichnoi samorealizatsii maibutnoho vchytelia (akmeolohichnyi aspekt) [Methodological and theoretical principles of professional and pedagogical self-realization of the future teacher (acmeological aspect)]. Zaporizhzhia: ZDMU [in Ukrainian].

Kryvylova, O., Sosnickaya, N., Oleksenko, K., Oleksenko, R., \& Khavina, I. (2021). The aqmeological framework for modern higher education as a step towards sustainable development of society. Linguistics and Culture Review, 5(S3), 55-64. https://doi.org/10.37028/lingcure.v5nS3.1369 [in English].

\section{АНОТАЦІЯ}

У статті розкрито сутність акмеологічного підходу в освітній галузі, який обрано для створення умов, що спонукають особистість до саморозвитку, самоорганізації та відповідно професійного самовдосконалення $d$ досягненні оптимального рівня профресійного розвитку. Визначено внутрішні умови 
досягнення професійного акме майстрів виробничого навчання: позитивна мотивація на досягнення очікуваних результатів з високим рівнем домагань та самореалізації; спрямованість на висхідну траєкторію профресійного иляху; продуктивна активність у виконанні професійних функцій; прагнення до збереження та примноження свої досягнень; здатність мобілізувати потенційні можливості (мотиваційні, інтелектуальні, операційно-діяльнісні, емоційновольові) та відновлюватися після фрізичного та психологічного навантаження.

Визначено зовнішні умови появи акме майстрів виробничого навчання: допомога в оволодінні засобами, необхідними для розвитку педагогічного мислення, творчості, індивідуальності особистості їі духовного потенціалу; забезпечення реалізації особистісно і соціально значущих перспектив у професійній діяльності; стимулювання процесу самовдосконалення; посилення інтеграційної ролі акме-психологічного супроводу як цілісного й безперервного процесу вивчення, аналізу, формування, розвитку, саморозвитку й корекції особистості фрахівця; розробка й реалізація відповідного змісту, моделей, алгоритмів акмеологічних технологій, адекватних засобів методичного забезпечення, діагностики й оцінки динаміки професійного розвитку.

Схарактеризовано інструментарій накопичення результатів професійної діяльності в контексті акме. Зокрема, акмеограма, у якій зазначаються види професійної діяльності та якості особистості, що сприяють не просто до отримання майстрами виробничого навчання соціально необхідного результату, але й забезпечують поступальний розвиток $i$ професійне вдосконалення, просування до високих рівнів профресіоналізму; портфоліо як опис у довільній фрормі освітніх та професійних здобутків майстрів виробничого навчання, який включає відомості про основні етапи діяльності, професійного вдосконалення, включно з досягнутими результатами, інфрормацію про участь у проєктах, публікації, методичні розробки тощо.

Ключові слова: акмеологія, майстер виробничого навчання, заклад профресійної освіти. 